\title{
Time- and stress-dependent model for predicting moisture retention capacity of high-food-waste-content municipal solid waste: based on experimental evidence*
}

\author{
Hui XU ${ }^{1}$, Liang-tong ZHAN ${ }^{\dagger 1}$, He LI ${ }^{1}$, Ji-wu LAN ${ }^{1}$, Yun-min CHEN $^{1}$, Hai-yan ZHOU ${ }^{2}$ \\ $\left({ }^{1}\right.$ MOE Key Laboratory of Soft Soils and Geoenvironmental Engineering, Zhejiang University, Hangzhou 310058, China) \\ ('Shanghai Laogang Wastes Disposal Co., Ltd., Shanghai 201302, China) \\ ${ }^{\dagger}$ E-mail: zhanlt@zju.edu.cn
}

Received Mar. 14, 2016; Revision accepted June 8, 2016; Crosschecked June 14, 2016

\begin{abstract}
Moisture retention capacity (MRC) is a key parameter for the prediction of leachate production of a municipal solid waste (MSW) pile. In this paper, five sets of laboratory tests were conducted in compression cells to characterize the variation of MRC with degradation time and overburden stress. Set A was conducted on the fresh high-food-waste-content (HFWC)-MSW under different degradation conditions and a sustained stress; Set B was on the fresh HFWC-MSW by alternation of degradation time and incremental stresses; Sets C, D, and E were on fresh HFWC-MSW, zero-food-waste-content (NFWC)-MSW, and decomposed MSW, respectively, being subjected to incremental stresses. The following findings were obtained from the test results: (1) The MRC of fresh HFWC-MSW decreased exponentially with degradation time under a sustained stress. The higher waste temperature or oxygen introduction would result in a faster declining of MRC. (2) The MRCs decreased linearly with a logarithmic increase of stress for all the MSW samples with different food waste contents. The MRC of HFWC-MSW was higher than that of NFWC-MSW under a given stress, and the decomposed MSW took the second place. (3) The variation of MRC appeared to be independent of stress path in terms of stress and degradation time. Based on the test results, the dependencies of the MRC of HFWC-MSW on degradation and stress were interpreted. Then, a time- and stress-dependent model was proposed for predicting the MRC of HFWC-MSW. The model was relatively simple and convenient for design purposes, and was verified by the measured data of leachate production at the pretreatment container of Laogang Incineration Plant. Finally, the model was developed to evaluate the dewatering effect of the HFWC-MSW pile. The strategy of combining the degradationenhancing measures with stress-increasing measures is recommended in a rapid dewatering project.
\end{abstract}

Key words: Moisture retention capacity (MRC), Municipal solid waste (MSW), Stress, Degradation http://dx.doi.org/10.1631/jzus.A1600238

CLC number: TU411

\section{Introduction}

Municipal solid waste (MSW) in Asian developing countries usually contains a large fraction of food waste, which leads to a high initial moisture

\footnotetext{
${ }^{\ddagger}$ Corresponding author

* Project supported by the National Basic Research Program (973 Program) of China (No. 2012CB719802), and the National Natural Science Foundation of China (No. 41502276)

(1D) ORCID: Hui XU, http://orcid.org/0000-0001-9283-8975; Liangtong ZHAN, http://orcid.org/0000-0002-4483-6737

(c) Zhejiang University and Springer-Verlag Berlin Heidelberg 2016
}

content of the MSW (Nie, 2008; Fang et al., 2012; Zhang et al., 2015). The high moisture content of MSW would result in multiple adverse impacts for MSW landfill. A large quantity of leachate would release from the MSW, contributing to a great leachate production at landfill sites (Zhan et al., 2015). On this basis, a build-up of leachate mound occurs within a landfill due to the inadequate drainage of leachate, which may induce a failure of a landfill slope (Koerner and Soong, 2000; Blight, 2008), a leachate leakage through the bottom liner (Schwarzbauer et al., 2002), and an impediment of gas collection 
(Rowe and Nadarajah, 1996; Jang, 2000; Zhan et al., 2015). In addition, the high moisture content of MSW presents challenges for MSW incineration. The average lower heating value (LHV) of MSW is typically lower than the minimum LHV of 6000$6500 \mathrm{~kJ} / \mathrm{kg}$ necessary for incineration without support firing, e.g., the average LHV equals $5000 \mathrm{~kJ} / \mathrm{kg}$ in China (Nie, 2008). As a result, the incineration technology achieves lower combustion efficiency and higher flue gas loss (Fu et al., 2015). Thus, the dewatering of MSW is a sensible option either as a pre-treatment before landfilling or as a pre-treatment before combustion. The prediction of leachate production of an MSW pile is thus important in the design of a dewatering programme.

Moisture retention capacity (MRC) is a key parameter for the prediction of leachate production of MSW landfill. MRC is defined as the amount of moisture that the MSW can retain against gravity. Fungaroli and Steiner (1979) reported an increasing trend of field capacity as the size of patterned milled refuse decreased after a typical American MSW, and also proposed a relationship between field capacity and density. Zornberg et al. (1999) carried out laboratory tests on waste samples from an American landfill site, and yielded a decreasing trend of gravimetric field capacity with depth and classified the mechanisms of moisture retention within the waste mass. Beaven (2000) investigated the hydrogeological properties of typical household waste in England contained in a large size compression cell $(2 \mathrm{~m}$ in diameter), and found that the gravimetric water content at field capacity of the waste reduced with increasing waste density and stress. de Velásquez et al. (2003) conducted field capacity tests on a typical Mexican MSW, and the results showed that the higher the compaction of the sample, the smaller the amount of water required to satisfy the field capacity and thus to start the leaching process. Tu et al. (2008) carried out laboratory tests to measure water holdup on artificial waste typical to China, and showed that the gravimetric water holdup of the waste decreases with increasing dry density. Further tests on field site specimens sampled from a Chinese landfill were carried out by $\mathrm{Tu}$ et al. (2010), and the results indicated that the gravimetric water holdup of the waste decreased with the increase of overburden pressure and burial depth. Arif (2010) carried out compression-permeability tests on fresh waste samples extracted from a French landfill site, and demonstrated that the leachate drained out from the samples with high initial moisture content after compressive stress had been applied. Lan (2012) carried out field capacity tests on the wastes sampled from a Chinese landfill, and found that the gravimetric field capacity decreased with an increase in applied stress. In summary, previous experimental studies mainly concentrated on the dependency of MRC on overburden stress, waste density, and the degree of degradation for the low-food-waste-content (LFWC)-MSWs generated in American and European countries. Based on experimental data, some empirical relationships were proposed for predicting MRC of the LFWC-MSWs. However, similar experimental data obtained from the high-food-wastecontent (HFWC)-MSWs generated in the Asian developing countries, such as China, is limited. Moisture retention behavior in the HFWC-MSW is more complicated than that in the LFWC-MSW. In addition, no theoretical model was proposed for predicting the dependency of MRC on overburden stress and the degree of degradation for the HFWC-MSWs.

In this paper, the MRC tests for HFWC-MSW, zero-food-waste-content (NFWC)-MSW, and decomposed MSW were conducted in compression cells. They were performed to characterize the change of MRC with degradation time and overburden stress. Based on the test results, the evolution mechanism of MRC of HFWC-MSW was analyzed, and a time- and stress-dependent model was proposed for MRC prediction. The model was verified by the measured data of leachate production at the pretreatment container of Laogang Incineration Plant, and further developed to evaluate the measures to enhance the dewatering effect of an HFWC-MSW pile.

\section{Materials and methods}

\subsection{Apparatus}

The compression cells are fabricated such that stress and temperature could be controlled and leachate could be collected. A schematic of the cell is shown in Fig. 1. Two types of stainless steel cylinders are used in the tests. Both of them have a 
height of $102 \mathrm{~cm}$, and one type has an inside diameter of $30 \mathrm{~cm}$, while the other is $40 \mathrm{~cm}$. The latter type is installed with two rows of air holes with the spacing of $10 \mathrm{~cm}$, to introduce the air into the waste naturally. A liquid injection and collection system is used to drain leachate from the bottom and saturate the specimen from the bottom or top. Vertical stress applied to the specimens is generated by means of dead-weight and hydro-cylinder loading systems. The dead-weight loading system is used to apply stress below $30 \mathrm{kPa}$, while the hydro-cylinder system is used for the range of $0-600 \mathrm{kPa}$. A thermostatic chamber is built for a stable temperature condition, and electrical heaters with temperature control are placed on both sides of the cell. Three exhaust outlets are installed on top of the chamber to promote air circulation. The temperature is controlled in the range of $(40 \pm 3){ }^{\circ} \mathrm{C}$, which is favorable for anaerobic degradation. The applied stress, temperature, settlement, and leachate flux are recorded manually. The settlement was measured by steel ruler from the top of the load plate.

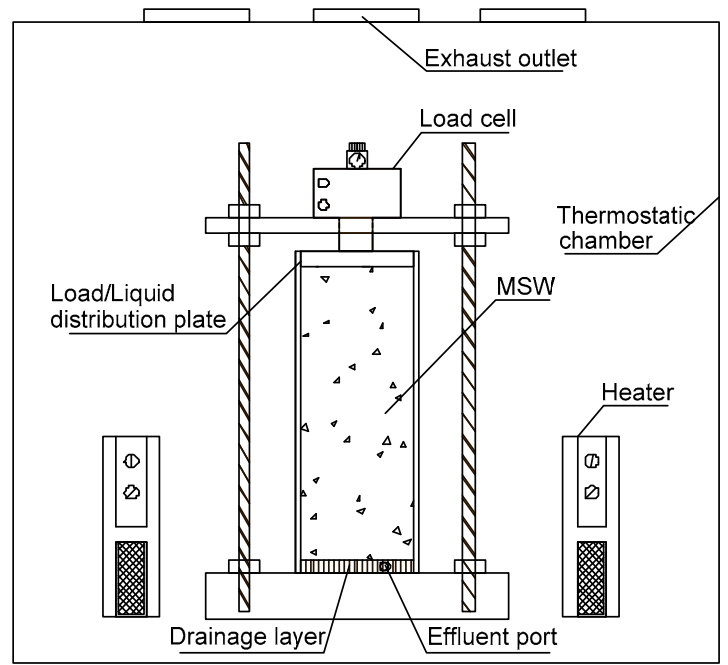

Fig. 1 Schematic of experimental cell

\subsection{Specimens}

The investigation was conducted on the composition and moisture content of fresh MSW in Hangzhou, China in 2010. The wet weight content and moisture content of waste material are given in Table 1. It shows that the food waste content of the MSW is as high as $60.1 \%$, and the initial moisture content is $62.6 \%$.
Three types of synthetic waste were used in the present tests. The HFWC-MSW was prepared based on the investigated data of MSW in Hangzhou. Prior to use, the food waste was held in the bucket to dewater from an initial moisture content of $84.0 \%$ to $76.6 \%$. Tap water was added to the other dry materials to reach the corresponding moisture content as listed in Table 1 . The maximum particle size was $30 \mathrm{~mm}$, and the ratio of cell diameter to maximum particle size is $10-13$. The NFWC-MSW was prepared based on the same material fraction as HFWCMSW, except for the component of food waste. Some of the prepared HFWC-MSW was placed in the waste container with a moisture content of $62.6 \%$ and temperature of $(40 \pm 3){ }^{\circ} \mathrm{C}$. After three years of degradation, the HFWC-MSW was taken out and dried at $70^{\circ} \mathrm{C}$ for $48 \mathrm{~h}$, as the decomposed MSW (DMSW). The content of the dry basis for D-MSW was then analyzed, as listed in Table 1. The ones difficult to determine were all regarded as soil-like materials.

The prepared waste was filled in approximately $0.3-\mathrm{m}$ thick lifts. Waste was weighed and dropped into the cell, then compacted manually to a certain thickness. The mass of the waste for each lift was estimated by dry density which was obtained from a similar filling process under a constant compaction load of $10 \mathrm{kPa}$. Subsequently, the waste was saturated by adding tap water from the upper distribution plate. The initial total waste thickness was $0.85 \mathrm{~m}$. For the cells with an inside diameter of $30 \mathrm{~cm}$, the masses of filled waste were 49.3, 40.4, and $26.5 \mathrm{~kg}$ for HFWC-MSW (wet mass), NFWC-MSW (wet mass), and D-MSW (dry mass), and the masses of additive water were 10,15 , and $30 \mathrm{~kg}$, respectively. For the cells with the inside diameter of $40 \mathrm{~cm}$, the masses of filled waste and additive water were 87.6 and $17.8 \mathrm{~kg}$ for HFWC-MSW, respectively. The initial moisture contents (wet mass basis) were $68.8 \%$, $57.4 \%$, and $53.1 \%$ for HFWC-MSW, NFWC-MSW, and D-MSW, respectively.

\subsection{Procedures}

A summary of the MRC tests conducted in this study is presented in Table 2 . All tests were conducted in cells with an inside diameter of $30 \mathrm{~cm}$, except for test A-3.

The tests, A-1, A-2, A-3, and A-4, were conducted on the fresh HFWC-MSW under different 
Table 1 Waste composition and related parameters

\begin{tabular}{|c|c|c|c|c|c|}
\hline \multirow[b]{2}{*}{ Material } & \multicolumn{2}{|c|}{ Hangzhou MSW } & \multirow{2}{*}{$\begin{array}{l}\text { HFWC-MSW } \\
\text { Content of wet } \\
\text { basis (\%) }\end{array}$} & \multirow{2}{*}{$\begin{array}{c}\text { NFWC-MSW } \\
\text { Content of wet } \\
\text { basis }(\%)\end{array}$} & \multirow{2}{*}{$\begin{array}{c}\text { D-MSW } \\
\text { Content of dry } \\
\text { basis }(\%)\end{array}$} \\
\hline & $\begin{array}{c}\text { Content of wet } \\
\text { basis }(\%)\end{array}$ & $\begin{array}{c}\text { Moisture content } \\
(\%)\end{array}$ & & & \\
\hline Food waste & 60.1 & 76.6 & 60.1 & 0 & 0 \\
\hline Paper & 11.1 & 53.3 & 11.1 & 27.7 & 0 \\
\hline Plastic & 17.4 & 43.1 & 17.4 & 43.5 & 37.0 \\
\hline Textile & 2.3 & 54.8 & 2.3 & 5.6 & 0 \\
\hline Wood & 1.9 & 23.0 & 1.9 & 4.8 & 0 \\
\hline Gravel & 0.5 & 11.1 & 0.5 & 1.2 & 1.7 \\
\hline Glass & 1.9 & 11.2 & 1.9 & 4.7 & 6.5 \\
\hline Metal & 0.6 & 7.1 & 0.6 & 1.4 & 2.1 \\
\hline Soil-like & 4.4 & 28.4 & 4.4 & 11.0 & 52.7 \\
\hline
\end{tabular}

Table 2 Summary of MRC tests

\begin{tabular}{|c|c|c|c|c|c|}
\hline No. & Waste type & $\begin{array}{l}\text { Stress range } \\
(\mathrm{kPa})\end{array}$ & Degradation condition & $\begin{array}{l}\text { Duration } \\
\text { time (d) }\end{array}$ & Research aim \\
\hline $\mathrm{A}-1, \mathrm{~A}-2$ & HFWC-MSW & 10 & $(40 \pm 3)^{\circ} \mathrm{C}$, anaerobic & 998 & \multirow{3}{*}{$\begin{array}{l}\text { Characterize the change of MRC } \\
\text { with degradation process }\end{array}$} \\
\hline A-3 & HFWC-MSW & 10 & $(40 \pm 3){ }^{\circ} \mathrm{C}$, semi-aerobic & 998 & \\
\hline A-4 & HFWC-MSW & 10 & $\begin{array}{l}\text { Ambient air tempera- } \\
\text { ture, anaerobic }\end{array}$ & 998 & \\
\hline B-1 & HFWC-MSW & $50-400$ & $(40 \pm 3)^{\circ} \mathrm{C}$, anaerobic & 400 & $\begin{array}{l}\text { Investigate the dependency of MRC } \\
\text { on the stress path }\end{array}$ \\
\hline $\mathrm{C}-1, \mathrm{C}-2$ & HFWC-MSW & $10-400$ & Degradation inhibited & 20 & \multirow{2}{*}{$\begin{array}{l}\text { Characterize the change of initial } \\
\text { MRC with incremental stresses }\end{array}$} \\
\hline D-1, D-2 & NFWC-MSW & $10-400$ & Degradation inhibited & 16 & \\
\hline E-1, E-2 & D-MSW & $10-400$ & Ambient air temperature & 14 & $\begin{array}{l}\text { Characterize the change of final } \\
\text { MRC with incremental stresses }\end{array}$ \\
\hline
\end{tabular}

degradation conditions, to characterize the change of MRC with the degradation process under a sustained stress. The parallel tests, A-1 and A-2, were conducted under an anaerobic degradation condition with a constant temperature of $(40 \pm 3){ }^{\circ} \mathrm{C}$, while A-3 was under a semi-aerobic condition with a temperature of $(40 \pm 3){ }^{\circ} \mathrm{C}$ and $\mathrm{A}-4$ was under the anaerobic degradation condition with ambient air temperature. After waste filling and water saturation, A-1, A-2, and A-3 were placed into the thermostatic chamber, while A-4 was outside the thermostatic chamber. Subsequently, a stress of $10 \mathrm{kPa}$ was applied using the dead-weight loading system, and the valve of the effluent port was then opened to discharge. On the days 222-243, the mature leachate taken from the anaerobically stabilized waste layer of the local landfill was filled into A-1 and A-2 to promote the degradation process. During the tests, the quantity of collected leachate was measured, denoted as $M\left(t_{i}\right)$. The four tests lasted for $998 \mathrm{~d}$. After completion of the test, the waste was taken from the cell and weighed for wet mass, denoted as $M_{\mathrm{tf}}$, and dry mass after drying at the temperature of $70{ }^{\circ} \mathrm{C}$ for $72 \mathrm{~h}$, denoted as $M_{\text {sf }}$.

The test B-1 was conducted on the fresh HFWC-MSW by alternation of incremental stresses and a degradation process, to investigate the dependency of MRC on the stress path. The operations were similar to the tests of A-1 and A-2. The stress was applied using the hydro-cylinder loading system, and the stress steps were 50, 100, 200, and $400 \mathrm{kPa}$. Each stress was held for $30 \mathrm{~d}$, except for the stress of $400 \mathrm{kPa}$, which continued for nearly 10 months. Finally, the test B-1 lasted for $400 \mathrm{~d}$.

The parallel tests, C-1 and C-2, were conducted on fresh HFWC-MSW under the condition of degradation inhibition, while D-1 and D-2 were on fresh NFWC-MSW. They were performed to determine the change in the initial MRC with the incremental stresses. The parallel tests, E-1 and E-2, were conducted on D-MSW, to obtain the change in the final MRC with the incremental stresses. The waste 
contained in C-1, C-2, D-1, and D-2 was saturated with acetic acid solution $(\mathrm{pH}=3)$ instead of tap water for other cells, so as to relieve the influence of waste degradation on MRC during the tests. After waste filling and water saturation, the cell was placed outside the thermostatic chamber. Subsequently, the first step stress was applied using the hydro-cylinder loading system, and the valve of the effluent port was then opened. The stress was applied incrementally from an initial $10 \mathrm{kPa}$ to the final $400 \mathrm{kPa}$, and each stress was held for $48 \mathrm{~h}$. During the tests, the quantity of collected leachate was measured, denoted as $M\left(\sigma_{j}\right)$.

\subsection{Data processing}

After draining for $24 \mathrm{~h}$ under free downward gravity, it was supposed that the filled waste had reached the state of MRC. In the following days, if there was no extra water added into the experimental cell, the waste always remained in the state of MRC. The MRCs of fresh and decomposed MSW under a given stress were considered as initial and final MRCs, respectively.

In the calculation of MRC for C-1, C-2, D-1, D-2, E-1, and E-2, the solid mass loss of the waste attributed to biodegradation was not taken into consideration. The measure of inhibiting degradation was adopted for C-1, C-2, D-1, and D-2, and little degradable material was contained in E-1 and E-2. Therefore, it is likely that no significant degradation would take place in the short duration of the tests. Thus, the MRC was calculated as

$\operatorname{MRC}\left(\sigma_{j}\right)=\left[M_{\mathrm{w} 0}-\sum_{j=1}^{j} M\left(\sigma_{j}\right)\right] /\left[M_{\mathrm{t}}-\sum_{j=1}^{j} M\left(\sigma_{j}\right)\right]$,

where $\operatorname{MRC}\left(\sigma_{j}\right)$ is the MRC of MSW under the stress of $\sigma_{j} ; M\left(\sigma_{j}\right)$ is the quantity of collected leachate under the stress of $\sigma_{j}, \mathrm{~kg} ; M_{\mathrm{t}}$ is the total mass of filled waste (including additive water), $\mathrm{kg} ; M_{\mathrm{w} 0}$ is the initial mass of water contained in waste (including additive water), $\mathrm{kg}$.

However, a considerable fraction of degradable material would be consumed during the long-term tests of A-1, A-2, A-3, A-4, and B-1. Therefore, the solid mass loss of the waste contained in the above cells should be taken into consideration. Using solely a reaction which decomposes the waste according to the first-order kinetics (Wall and Zeiss 1995), the MRC can be obtained as

$$
\operatorname{MRC}\left(t_{i}\right)=\frac{M_{\mathrm{w} 0}-\sum_{i=1}^{i} M\left(t_{i}\right)}{M_{\mathrm{t}}-\sum_{i=1}^{i} M\left(t_{i}\right)-\left(M_{\mathrm{s} 0}-M_{\mathrm{sf}}\right)\left(1-\mathrm{e}^{-k t_{i}}\right)},
$$

where $\operatorname{MRC}\left(t_{i}\right)$ is the MRC of the waste on the $i$ th day; $M\left(t_{i}\right)$ is the quantity of collected leachate on the $i$ th day, $\mathrm{kg} ; M_{\mathrm{s} 0}$ and $M_{\mathrm{sf}}$ are the dry masses of filled waste at the initial and final states, respectively, $\mathrm{kg} ; k$ is the hydrolysis rate constant of degradable material, $\mathrm{d}^{-1}$. The value of $k$ is calculated from the first-order kinetics equation, and the day when the collected leachate is smaller than $0.1 \%$ of the initial waste mass is chosen as the end time of waste mass loss.

\section{Results and analysis}

\subsection{Variation of MRC with degradation time un- der sustained stress}

Fig. 2a shows the temporal variations of MRC, leachate $\mathrm{pH}$, and chemical oxygen demand (COD) for A-1 and A-2. It appears that the test results were basically consistent for A-1 and A-2. In the first $90 \mathrm{~d}$, the MRC quickly declined from an initial $63.3 \%$ $63.7 \%$ to $51.3 \%-52.5 \%$, and the leachate $\mathrm{pH}$ rose up from an initial 5.0 to around 6.2 and COD increased from an initial $17 \mathrm{~g} / \mathrm{L}$ to $66-68 \mathrm{~g} / \mathrm{L}$. Subsequently, the leachate $\mathrm{pH}$ remained stable at about 6.2 and COD decreased to $61.5-63.5 \mathrm{~g} / \mathrm{L}$ during days $91-$ 221. It appears that the acid accumulation tended to inhibit any further degradation. During that time, the MRC remained approximately stable at $50.9 \%^{-}$ $52.2 \%$. To accelerate the degradation, the measure of mature leachate recirculation was then adopted. After the treatment, the $\mathrm{pH}$ jumped to the high level of around 8.0, and COD concentration further reduced to a low level of $2-3 \mathrm{~g} / \mathrm{L}$. It indicated that mature leachate recirculation was efficient in promoting degradation. As a result, the MRC began to decrease rapidly. After the treatment of $410 \mathrm{~d}$, the MRC further reduced to $45.7 \%-46.5 \%$, and kept stable in the following 12 months. The degree of saturation was also calculated from the MRC and settlement data. 
The saturation decreased from 0.73 to 0.61 in the first $90 \mathrm{~d}$, further decreased to 0.55 on day 221 , and remained at 0.40 over the following 12 months.
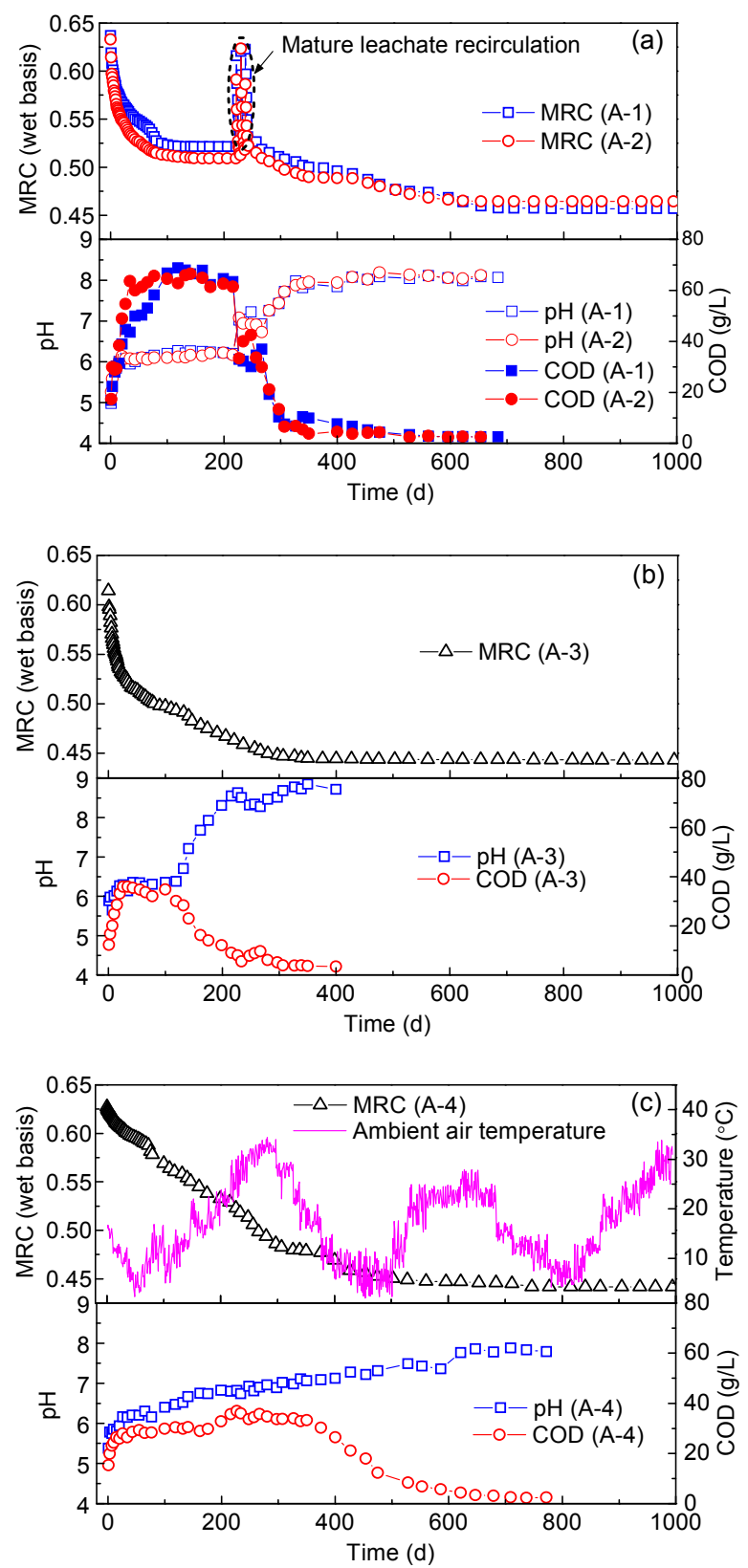

Fig. 2 Temporal variations of waste MRC, leachate $\mathrm{pH}$, COD, and ambient air temperature

(a) A-1 and A-2; (b) A-3; (c) A-4

Fig. $2 b$ shows the temporal variations of MRC, leachate $\mathrm{pH}$, and $\mathrm{COD}$ for A-3. The initial MRC was $61.4 \%$, and dropped to $49.8 \%$ in the following $90 \mathrm{~d}$. Subsequently, the MRC slowly declined to $49.1 \%$ during days $91-132$. The leachate $\mathrm{pH}$ rapidly rose from an initial 5.9 to 6.3 , and COD increased from an initial $12.3 \mathrm{~g} / \mathrm{L}$ to $36 \mathrm{~g} / \mathrm{L}$ in the first $26 \mathrm{~d}$. During days $27-119$, pH slightly increased to 6.4 , and COD slightly decreased to $30.1 \mathrm{~g} / \mathrm{L}$. It appears that the acid accumulation slightly slowed down the decline of MRC. From day 120 on, the pH rapidly increased to a high value of around 8.8 , and the COD rapidly declined to a low level of $3.5 \mathrm{~g} / \mathrm{L}$. It indicates that a favorable degradation environment was achieved. As a result, the decline of MRC speeded up from day 133 on. The MRC further reduced to $44.4 \%$ on day 376 , and remained stable over the following 20 months. The degree of saturation decreased from 0.67 to 0.50 in the first $90 \mathrm{~d}$, and further decreased to 0.45 on day 132 , and remained at 0.38 over the following 20 months.

Fig. 2c shows the temporal variations of MRC, leachate $\mathrm{pH}, \mathrm{COD}$, and ambient air temperature for A-4. The MRC declined from an initial $62.7 \%$ to $57.2 \%$ in the first $90 \mathrm{~d}$. At that time, the leachate $\mathrm{pH}$ gradually increased from an initial 5.4 to about 6.3, and COD increased from an initial $15.4 \mathrm{~g} / \mathrm{L}$ to $29.0 \mathrm{~g} / \mathrm{L}$. It appears that the MRC reduction rate and COD concentration of A-4 were both lower than those of A-1, A-2, and A-3. This may be related to the slow hydrolysis process caused by the low temperature of below $15{ }^{\circ} \mathrm{C}$ during that time. Subsequently, the COD increased to the peak value of $37.0 \mathrm{~g} / \mathrm{L}$ in the first $227 \mathrm{~d}$, and declined to around $2.4 \mathrm{~g} / \mathrm{L}$ in the following 18 months. The leachate $\mathrm{pH}$ further increased to 7.8 on day 621 , and remained around 7.8 over the following five months. It appears that the low degradation process resulted in a slow decline of MRC. The MRC slowly reduced to $44.7 \%$ on day 596, and finally remained around $44.2 \%$. The degree of saturation decreased from 0.73 to 0.62 in the first $90 \mathrm{~d}$, and further decreased to 0.42 on day 596, and remained at 0.39 over the following 20 months.

The above results indicate that both the initial and final MRCs of HFWC-MSW were close under different degradation conditions. However, the variation processes of MRC from the initial state to the final state were greatly different. It seemed that the variation of MRC was significantly related to the degradation conditions. The detailed explanation will be given later in this study. 
To simulate the temporal variation of MRC for fresh HFWC-MSW, the following equation was adopted:

$$
\operatorname{MRC}(t)=\mathrm{MRC}_{0}-\Delta \operatorname{MRC}\left(1-\mathrm{e}^{-m t^{n}}\right)
$$

where $\mathrm{MRC}_{0}$ is the initial MRC, $\triangle \mathrm{MRC}$ is the difference value between initial and final MRC, and $m$ and $n$ are both rate constants associated with the temporal variation of MRC. Fig. 3 shows the fitting results of $\mathrm{MRC}$ for $\mathrm{A}-1-\mathrm{A}-4$. In the calculation, the average MRC of A-1 and A-2 was adopted. The fitting curve was $\operatorname{MRC}(t)=0.635-0.184 \times[1-$ $\left.\exp \left(-0.08 t^{0.58}\right)\right]$ for A-1 and A-2 without the inhibition of degradation, while it was $\operatorname{MRC}(t)=0.614-$ $0.173 \times\left[1-\exp \left(-0.11 t^{0.53}\right)\right]$ for $\mathrm{A}-3$, and $\operatorname{MRC}(t)=$ $0.627-0.185 \times\left[1-\exp \left(-0.005 t^{0.98}\right)\right]$ for A-4. It can be observed that the fitting results were in good agreement with the test data, even for the rapidly declining stage in the first $30 \mathrm{~d}$.

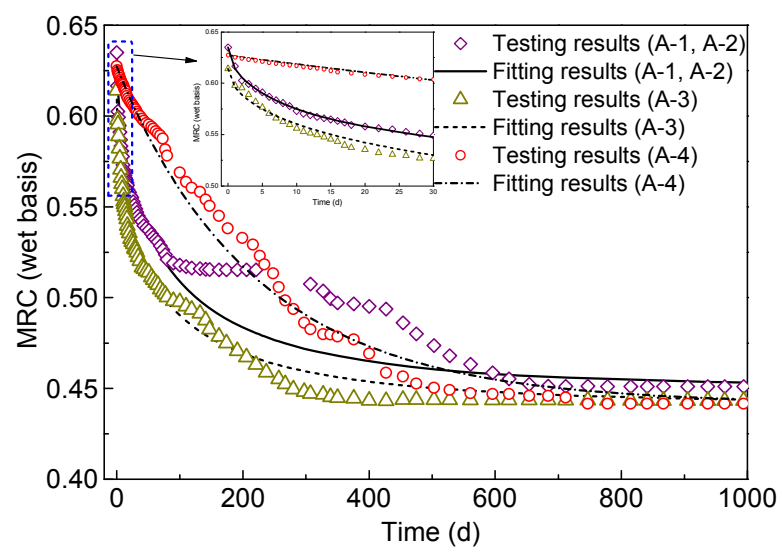

Fig. 3 Comparison of testing and fitting results of MRC varying with time

\subsection{Variation of MRC with degradation time un- der incremental stresses}

Fig. 4a shows the temporal variation of MRC for B-1. The initial MRC was 55.2\% under the first vertical stress of $50 \mathrm{kPa}$, much lower than those from the tests A-1-A-4. $30 \mathrm{~d}$ after the application of the first stress, the MRC decreased to $48.3 \%$. The MRC dropped to $45.3 \%$ after the application of the second stress of $100 \mathrm{kPa}$, and further decreased to $42.6 \%$ in the following $30 \mathrm{~d}$. Similarly, the MRC dropped to $40.3 \%$ after the application of the third stress of
$200 \mathrm{kPa}$, and further decreased to $38.7 \%$ in the following $30 \mathrm{~d}$. Again, the MRC dropped to $36.8 \%$ after the application of the fourth stress of $400 \mathrm{kPa}$, and further decreased to $35.1 \%$ in the following 10 months. The results indicated that the MRC dropped after the application of an incremental stress, and further decreased in the following days.

Fig. $4 \mathrm{~b}$ shows the temporal variations of leachate $\mathrm{pH}$ and $\mathrm{COD}$ for B-1. After $30 \mathrm{~d}$ from the application of the first vertical stress of $50 \mathrm{kPa}$, the leachate $\mathrm{pH}$ rose from 5.5 to around 6.0, and COD rapidly increased from $32.3 \mathrm{~g} / \mathrm{L}$ to about $66.5 \mathrm{~g} / \mathrm{L}$. After the application of the second stress of $100 \mathrm{kPa}$, the $\mathrm{pH}$ decreased to 5.6 and COD further increased to $74.9 \mathrm{~g} / \mathrm{L}$ instantaneously. In the following $30 \mathrm{~d}, \mathrm{pH}$ rose to 6.3 and COD decreased to $55.4 \mathrm{~g} / \mathrm{L}$. Similarly, the $\mathrm{pH}$ decreased to 6.0 and COD increased to $63.9 \mathrm{~g} / \mathrm{L}$ instantaneously after the application of the third stress of $200 \mathrm{kPa}$, and the $\mathrm{pH}$ rose to 6.6 and COD decreased to $32.4 \mathrm{~g} / \mathrm{L}$ in the following $30 \mathrm{~d}$. Again, after the application of the fourth stress of $400 \mathrm{kPa}$, the $\mathrm{pH}$ decreased to 6.1 and COD increased to $52.8 \mathrm{~g} / \mathrm{L}$ instantaneously. In the following 10 months, $\mathrm{pH}$ rose to 7.7 and COD decreased to $3.0 \mathrm{~g} / \mathrm{L}$. The results indicated that the leachate $\mathrm{pH}$ decreased and COD increased instantaneously after the application of an incremental stress, and then $\mathrm{pH}$ increased and COD decreased in the following days.

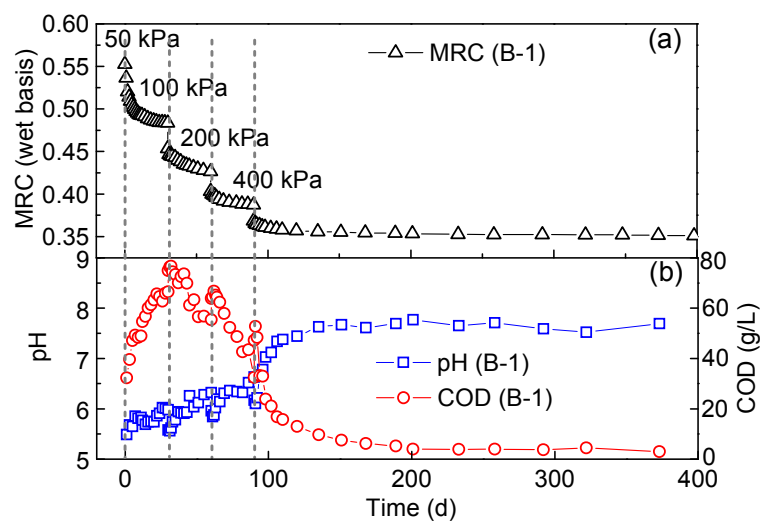

Fig. 4 Variations of MRC (a), leachate pH and COD (b) with alternation of incremental stresses and degradation time for B-1

\subsection{Variation of MRC with incremental stresses}

Fig. 5 shows the variations of MRC with stresses for fresh HFWC-MSW (C-1 and C-2), fresh NFWC-MSW (D-1 and D-2), and decomposed 
MSW (E-1 and E-2). When the vertical stress increased from $10 \mathrm{kPa}$ to $400 \mathrm{kPa}$, the average MRC decreased from $63.0 \%$ to $46.0 \%$ for HFWC-MSW, from $46.5 \%$ to $35.3 \%$ for decomposed MSW, and from $37.9 \%$ to $30.4 \%$ for NFWC-MSW. It was observed that the MRC of HFWC-MSW was higher than that of NFWC-MSW under a given stress, and the decomposed MSW took the second place. The results also indicated that the MRC appeared to decrease linearly with an increase of logarithmic stress for the three types of MSWs. The fitting curves were $\operatorname{MRC}(\sigma)=0.754-0.112 \lg \sigma, \operatorname{MRC}(\sigma)=0.424-0.047 \lg \sigma$, and $\operatorname{MRC}(\sigma)=0.521-0.067 \lg \sigma$ for HFWC-MSW, NFWC-MSW, and decomposed MSW, respectively. In addition, these three fitting lines intersect approximately at the point $(120000,0.185)$.

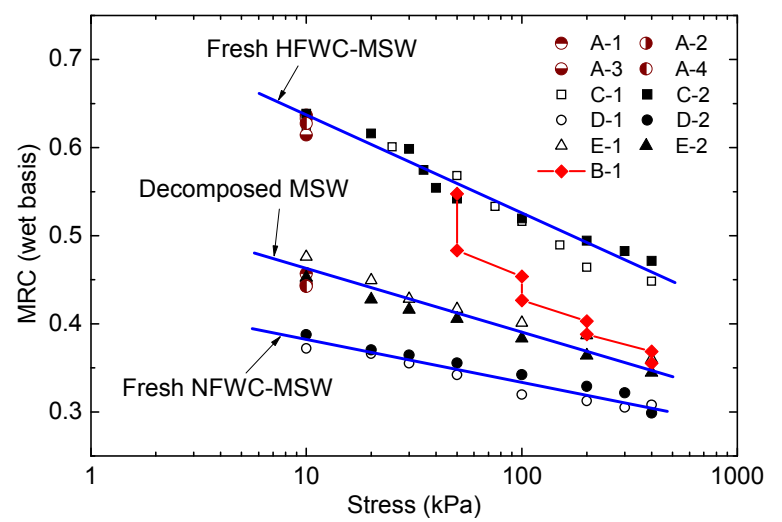

Fig. 5 Variation of MRC with incremental stresses for different types of MSWs

Fig. 5 shows the initial and final values of MRC for A-1-A-4. The initial and final values were all approximate to the fitting curves for fresh HFWCMSW and decomposed MSW, respectively. It indicated that the test results were quite reliable. Fig. 5 also shows the variation of MRC with incremental stresses for B-1. The initial MRC was close to the fitting curve for fresh HFWC-MSW under the stress of $50 \mathrm{kPa}$. After the alternating process of degradation and incremental stresses, the final MRC was close to the fitting curve for decomposed MSW under the stress of $200 \mathrm{kPa}$. The results from the above five tests implied that the variation of MRC was independent of stress path in terms of stress and degradation time.

\subsection{Evolution mechanism of MRC with stress and degradation}

To characterize the amount of liquids within the MSW pile, mechanisms of moisture retention within the waste mass can be classified as the ones within and between waste particles (Zornberg et al., 1999), as shown in Fig. 6. The moisture within waste particles (i.e., within intra-particle voids) is mainly contained in the food waste of fresh MSW, and constrained by cell wall or membrane (Zhang et al., 2008). The moisture between waste particles (i.e., within inter-particle voids) is mainly held by capillary stress, and exits in both fresh and decomposed MSW. In present tests, both intra-particle and interparticle water existed in the HFWC-MSW, and solely inter-particle water existed in the NFWC-MSW and decomposed MSW.

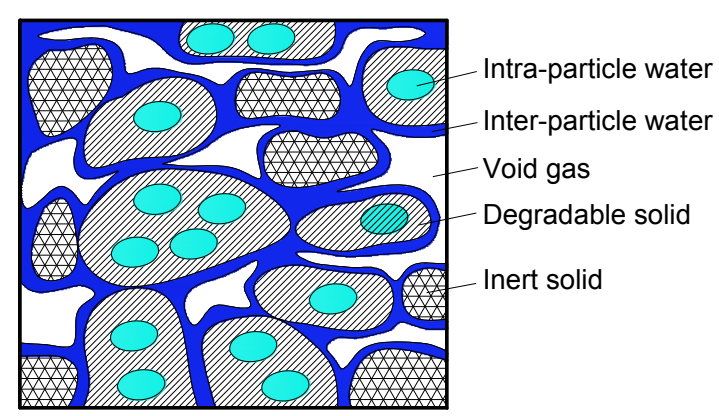

Fig. 6 Moisture forms existing in MSW

Before the following analyses, an assumption was made that the inter-particle water retained in fresh HFWC-MSW was equal to that in fresh NFWC-MSW at a given stress. This assumption was made in consideration of the similar size and distribution of waste particles in the above two types of specimens.

According to Section 3.3, the MRC of decomposed MSW was higher than that of fresh NFWCMSW at a given stress. Moreover, the MRCs of decomposed waste with different compositions were quite consistent at a given stress (Fig. 9). Therefore, it was considered that the inter-particle water retained in MSW increased with degradation time. In addition, the MRC of fresh HFWC-MSW decreased with degradation time under sustained stress according to Section 3.1. Thus, it can be further inferred that the intra-particle water retained in MSW 
decreased with degradation time. On account of these, the influence mechanism of degradation to the MRC of MSW was clear, as shown in Fig. 7a. After the placement of the MSW, the macromolecular compounds contained in easily hydrolyzed materials, such as cellulose, lipid, protein, and carbohydrate, were decomposed into small molecule organic acid. This process would lead to the following results. First, the intra-particle water constrained by cell wall or membrane was released into inter-particle water, leading to a decrease in the retention capacity of intra-particle water. Second, the degradable solid was decomposed into small particles, leading to an increase in the retention capacity of inter-particle water. As for fresh HFWC-MSW, the decreasing rate of retention capacity of intra-particle water was larger than the increasing rate of retention capacity of inter-particle water in the early degradation period. Therefore, the MRC of fresh HFWC-MSW declined with degradation time, and the decline rate would be increased due to the acceleration of the hydrolysis process. Conversely, the inhibition of the hydrolysis process would lead to a reduction of the decline rate of MRC. In addition, the release of intra-particle water would be slower in the late degradation period, which also resulted in a decrease in the decline rate of MRC.

Based on the above assumption, the difference value of MRC between fresh HFWC-MSW and NFWC-MSW was considered as intra-particle water retained in fresh HFWC-MSW. On account of this, the retained intra-particle water decreased from $25.1 \%$ to $15.6 \%$ with the stress increased from 10 to $400 \mathrm{kPa}$. It demonstrated a clear trend that the retained intra-particle water decreased with an increase in stress. In addition, the inter-particle water retained in both fresh NFWC-MSW and decomposed MSW decreased with stress according to Section 3.3. On these accounts, the influence mechanism of stress compression to the MRC of MSW was clear, as shown in Fig. 7b. First, the void between waste particles decreased under the stress compression, leading to a decrease in retention capacity of interparticle water. Second, the cell wall or membrane was destroyed under mechanical compression, leading to the release of intra-particle water, and this further resulted in a decrease in retention capacity of intra-particle water.
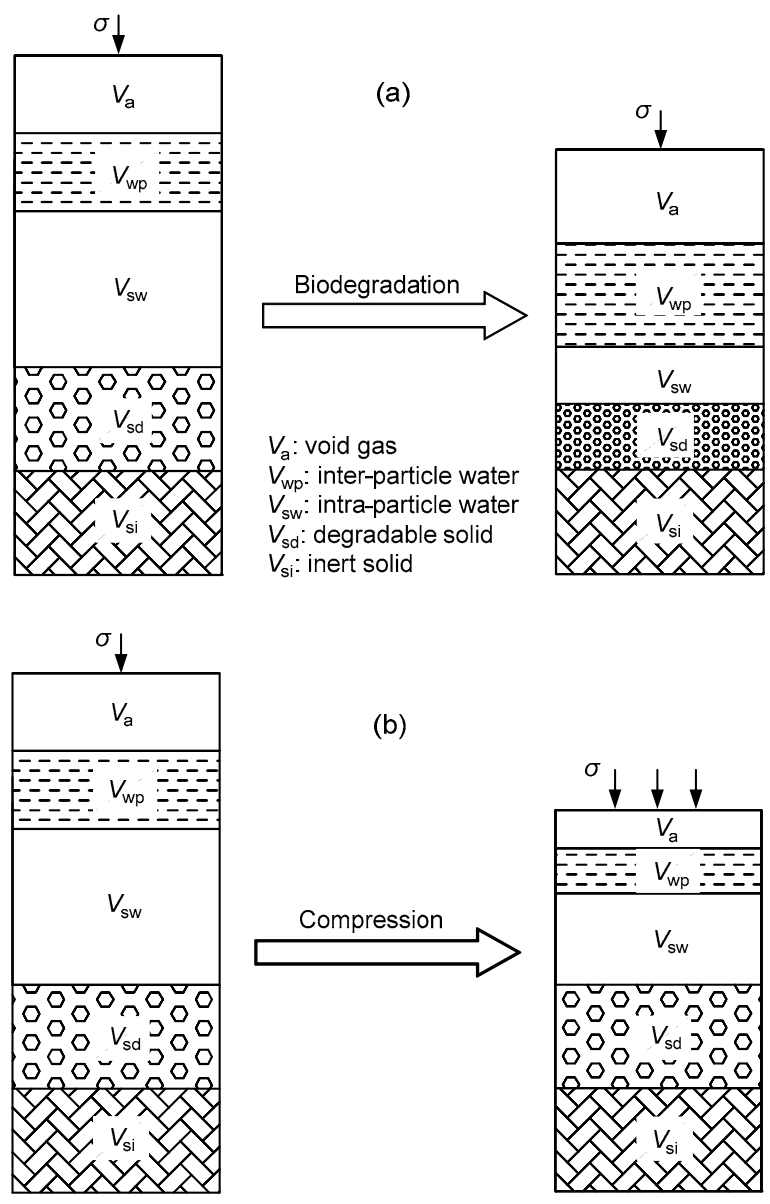

Fig. 7 Variation mechanisms of MRC with degradation (a) and stress compression (b)

\section{Mathematical model for predicting of MRC}

\subsection{Basic assumptions and modelling}

Fig. 8 shows the conceptual model for predicting the dependency of MRC on degradation and stress for MSW. In the modelling, some assumptions are made based on the above findings:

1. The MRC decreases linearly with logarithmic stress both for fresh and decomposed MSWs, and the two curves intersected at the point $\left(\lg \sigma^{*}, M C^{*}\right)$.

2. The MRC decreases composite-exponentially with degradation time for fresh HFWC-MSW under a sustained stress.

3. The variation of MRC was independent of stress path in terms of stress and degradation time.

Based on the assumptions, a mathematical model for predicting the MRC of MSW was proposed: 
$\operatorname{MRC}(\sigma, t)=$

$\operatorname{MRC}(\sigma, 0)-[\operatorname{MRC}(\sigma, 0)-\operatorname{MRC}(\sigma, \infty)]\left(1-\mathrm{e}^{-m t^{n}}\right)$,

where $\operatorname{MRC}(\sigma, 0)$ and $\operatorname{MRC}(\sigma, \infty)$ are the initial and final MRCs of MSW under the stress of $\sigma$, respectively. They can be obtained from the following equations:

$$
\begin{aligned}
& \operatorname{MRC}(\sigma, 0)=\mathrm{MRC}^{*}-C_{0} \lg \left(\frac{\sigma^{*}}{\sigma}\right), \\
& \operatorname{MRC}(\sigma, \infty)=\operatorname{MRC}^{*}-C_{\infty} \lg \left(\frac{\sigma^{*}}{\sigma}\right),
\end{aligned}
$$

where $C_{0}$ and $C_{\infty}$ are the slopes of the MRC-lg $\sigma$ curves for fresh and decomposed MSWs, respectively. Then, Eq. (4) can be rewritten as

$$
\begin{aligned}
\operatorname{MRC}(\sigma, t)= & \mathrm{MRC}^{*}-C_{0} \lg \left(\frac{\sigma^{*}}{\sigma}\right) \\
& -\left(C_{\infty}-C_{0}\right) \lg \left(\frac{\sigma^{*}}{\sigma}\right)\left(1-\mathrm{e}^{-m t^{n}}\right) .
\end{aligned}
$$

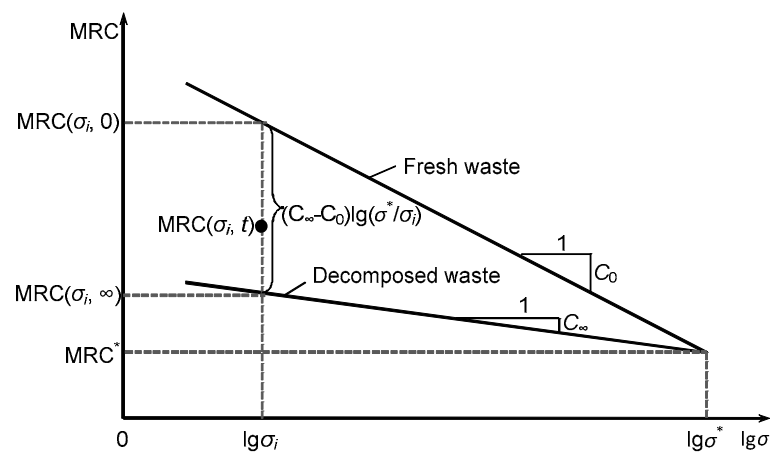

Fig. 8 Conceptual model for MRC prediction of MSW

\subsection{Parameter determination}

To achieve satisfactory predictions with the proposed MRC model, the parameters should be determined via the following tests:

1. Conduct a short-term MRC test on a fresh MSW sample under incremental stresses, to determine the parameter $C_{0}$. The degradation process should be inhibited by adding acetic acid solution with $\mathrm{pH}$ lower than 3.0. The elapsed time associated with each applied stress must be sufficiently long (i.e., greater than $24 \mathrm{~h}$ ).

2. Perform a long-term MRC test on a fresh MSW sample under the scenario of a sustained stress and degradation conditions similar to those in the actual MSW pile (i.e., temperature, water content, $\mathrm{pH}$ value), to determine the parameters $m$ and $n$. The elapsed time must be long enough to reach the state of final MRC.

3. Decomposed MSW is obtained after the test of step 2. Conduct a short-term MRC test on the decomosed MSW sample under the incremental stresses, to determine the parameter $C_{\infty}$. The elapsed time associated with each applied stress must be greater than $24 \mathrm{~h}$.

4. Fit the data points from the short-term MRC test on fresh and decomposed MSW. Furthermore, calculate the intersecting point of the two fitting curves, $\left(\lg \sigma^{*}, \mathrm{MRC}^{*}\right)$.

For convenience, this study also gives the following method to estimate the parameters associated with the proposed model:

1. An assumption is made that the relationships are consistent for different compositions of decomposed MSW. Based on the present test results, the MRC-lg $\sigma$ curve for decomposed MSW is recommended as

$$
\operatorname{MRC}(\sigma, \infty)=0.521-0.067 \lg \sigma \text {. }
$$

2. The following assumptions are made: (1) the MRC-lg $\sigma$ curves for fresh MSW with different compositions intersected at the point $\left(\lg \sigma^{*}, \mathrm{MRC}^{*}\right)$; (2) the parameter $C_{0}$ is associated with food waste content (FWC) of fresh MSW, and the relationship can be expressed as

$$
C_{0}=C_{a}+\frac{C_{b}-C_{a}}{b-a} \mathrm{FWC},
$$

where $C_{a}$ and $C_{b}$ are the slopes of the MRC- $\lg \sigma$ curves for fresh $\mathrm{MSW}$ with $\mathrm{FWC}=a$ and $\mathrm{FWC}=b$, respectively. Based on the present test results, the parameters $\sigma^{*}, \mathrm{MRC}^{*}, C_{0 \%}$, and $C_{60 \%}$ are 120000 , $0.185,0.047$, and 0.112 , respectively. Then, the equation for estimating the MRC of fresh MSW with different FWCs can be expressed as 


$$
\begin{aligned}
\operatorname{MRC}(\sigma, 0) & =\mathrm{MRC}^{*}-C_{0} \lg \left(\frac{\sigma^{*}}{\sigma}\right) \\
= & 0.185+(0.047-0.108 \mathrm{FWC})(5.079-\lg \sigma) .
\end{aligned}
$$

3. The parameters $m$ and $n$ can be adopted with or referenced to the values obtained from the present tests. The obtained values of $m$ and $n$ recommended for the three different degradation conditions are shown in Table 3.

Table $3 \boldsymbol{m}$ and $\boldsymbol{n}$ for different degradation conditions

\begin{tabular}{lcll}
\hline Degradation type & $\begin{array}{c}\text { Temperature } \\
\text { condition }\end{array}$ & $m\left(\mathrm{~d}^{-1}\right)$ & $n$ \\
\hline Anaerobic & Ambient air temp. & 0.005 & 0.98 \\
Anaerobic & $(40 \pm 3)^{\circ} \mathrm{C}$ & 0.08 & 0.58 \\
Semi-aerobic & $(40 \pm 3)^{\circ} \mathrm{C}$ & 0.11 & 0.53 \\
\hline
\end{tabular}

Fig. 9 shows the comparison between the measured data from references and the recommended curve for decomposed MSW. Zornberg et al. (1999) conducted MRC tests in a 450-mm-diameter cell. The specimens were obtained from drilling at the depth of 15-60 $\mathrm{m}$ in a Southern California Landfill (USA), and contained a large proportion of soillike and inert materials. The measured MRC decreased from $60.2 \%$ to $40.5 \%$ with an increase of stress from 206.8 to $827.4 \mathrm{kPa}$. Beaven (2000) conducted MRC tests in a large-scale (2-m diameter) compression cell. The specimens were excavated from Cleanaway Ltd.'s Rainham (UK) landfill site, and had a landfilled age of over 20 years and a large proportion of soil-like material. The results indicated that the MRC reduced with increasing applied stress, from approximately $43.0 \%$ at an applied stress of $40 \mathrm{kPa}$ to $33.6 \%$ at the stress of $603 \mathrm{kPa}$. Tu et al. (2010) conducted MRC tests in a 152-mm-diameter compression cell. The specimens were drilled from the depth of $22.5 \mathrm{~m}$ at an MSW landfill in South China, and had a landfilled age of over 10 years and a proportion of over $85 \%$ for soil-like and inert materials. The results showed that the MRC reduced from $47.9 \%$ to $31.6 \%$ with the applied stress increased from 8.3 to $439 \mathrm{kPa}$. The specimens used in the above tests all had the appearance of decomposed MSW. It was observed that the MRCs of decomposed waste from different sites (i.e., with dif- ferent compositions) were quite consistent at a given stress. In addition, the recommended curve for decomposed MSW was in good agreement with the measured data from references.

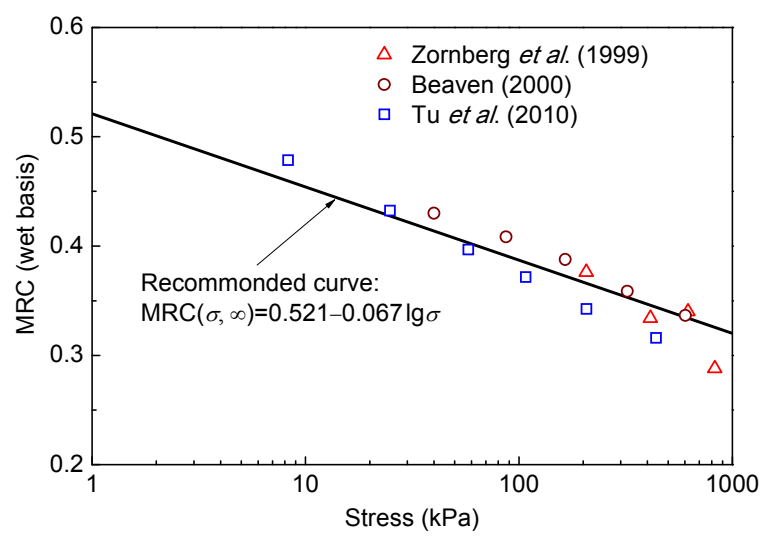

Fig. 9 Comparison of MRC between recommended curve and measured data

Fig. 10 shows the comparison between measured data from references and the estimated curves for fresh MSW. Lan (2012) conducted MRC tests in a 400-mm-diameter compression cell. The fresh specimens were picked from an MSW landfill in South China, and had an FWC of $60 \%$. The results indicated that the MRC decreased with increasing stress, from $59.3 \%$ at the stress of $40 \mathrm{kPa}$ to $44.3 \%$ at the stress of $800 \mathrm{kPa}$. Arif (2010) conducted compression-permeability tests in a 270 -mm-diameter compression cell. The fresh specimens were extracted from a French landfill site operated by Véolia Environment, and had an FWC of 58\%. The results showed that the MRC decreased from $59.0 \%$ to $50.5 \%$ with the stress increased from 20 to $200 \mathrm{kPa}$. Tu et al. (2008) conducted MRC tests in a $152-\mathrm{mm}-$ diameter compression cell. The fresh specimens were artificially prepared based on the composition noted for an MSW landfill in South China. The food waste was simulated by bran to a fraction of $30 \%$. The results showed that the MRC reduced from $41.0 \%$ to $32.0 \%$ with the applied stress increased from 100 to $600 \mathrm{kPa}$. It was observed that the estimated curves were in good agreement with the measured data from Lan (2012) and Arif (2010). However, the estimated results were higher than those from $\mathrm{Tu}$ et al. (2008). The reason was 
concerned with the use of bran to simulate the food waste in the test. As a result, there was no intraparticle water retaining in the fresh specimen, leading to a lower MRC than that in the scenario of using real food waste materials. Therefore, it was reasonable that the measured data from Tu et al. (2008) fell between the curves of $\mathrm{FWC}=30 \%$ and $\mathrm{FWC}=0 \%$.

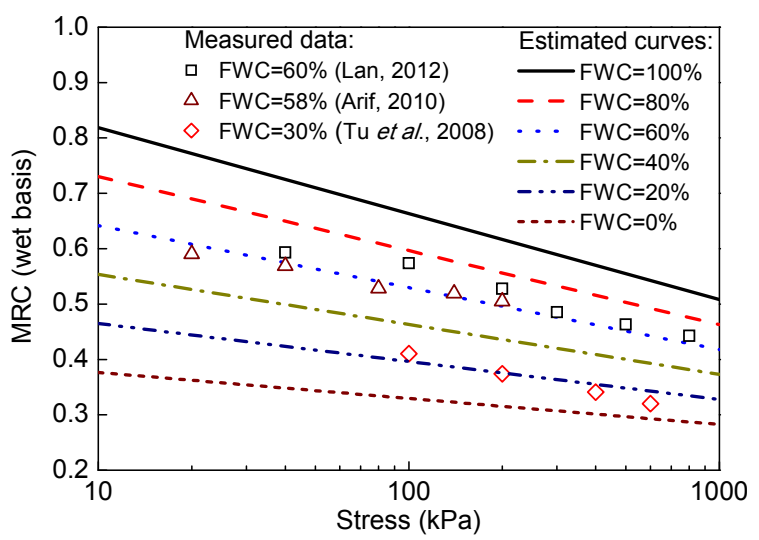

Fig. 10 Comparison of MRC for fresh MSW between estimated curves and measured data

\section{Engineering application}

\subsection{Predicting of leachate production of MSW pile}

The Laogang Incineration Plant, installed in the Pudong New Area of Shanghai, is one of the largest incineration plants in China. The treatment capacity of MSW is $3300 \mathrm{t} / \mathrm{d}$. Two pre-treatment containers were designed to store the MSW to be drained for days to reduce the moisture content before combustion. Each container had the dimension of $55 \mathrm{~m}$ in length, $27 \mathrm{~m}$ in width, and $33 \mathrm{~m}$ in height. In summer days, the received MSW was stacked to a height of $22-25 \mathrm{~m}$ and drained for 3-4 d before combustion. As a result, $750-850 \mathrm{t}$ of water were removed from the received $3300 \mathrm{t}$ of MSW every day.

To verify the MRC model proposed in this study, the calculated leachate production at the pretreatment container was compared with the measured data. The profile of the simplified MSW pile with initial and boundary conditions is shown in Fig. 11. According to the data from management department of Laogang Incineration Plant and Lan (2012), the received MSW had a food waste content of about $60 \%$ and an initial moisture content of nearly $64 \%$ in summer days. In addition, the average height of the MSW pile was $23.5 \mathrm{~m}$, then the average unit weight was calculated as $10.1 \mathrm{kN} / \mathrm{m}^{3}$ based on the unit weight profile suggested by Chen et al. (2009). In addition, a surcharge loading of $\sigma_{\mathrm{p}}$ was applied on top of the MSW pile, and the leachate could flow out freely from the bottom. The leachate production can be obtained from the following equation:

$$
Q(t)=\left.M \frac{w_{\mathrm{w} 0}-\operatorname{MRC}(\sigma, t)}{1-\operatorname{MRC}(\sigma, t)}\right|_{\sigma=0.5 \gamma H+\sigma_{\mathrm{p}}}
$$

where $w_{\mathrm{w} 0}$ is the initial moisture content, $\gamma$ is the average unit weight, and $H$ is the average stacked height. $\operatorname{MRC}(\sigma, t)$ can be calculated from Eq. (6). The recommended values of $C_{\infty}, \sigma^{*}$, and $\mathrm{MRC}^{*}$ are used in the calculation. The parameter $C_{0}$ is adopted as -0.125 based on the measured data from Lan (2012), and $m$ and $n$ are adopted as 0.11 and 0.53 , respectively, based on the similar degradation conditions in Table 3. In this scenario, no surcharge loading is applied on top of the MSW pile, i.e., $\sigma_{\mathrm{p}}=0 \mathrm{kPa}$.

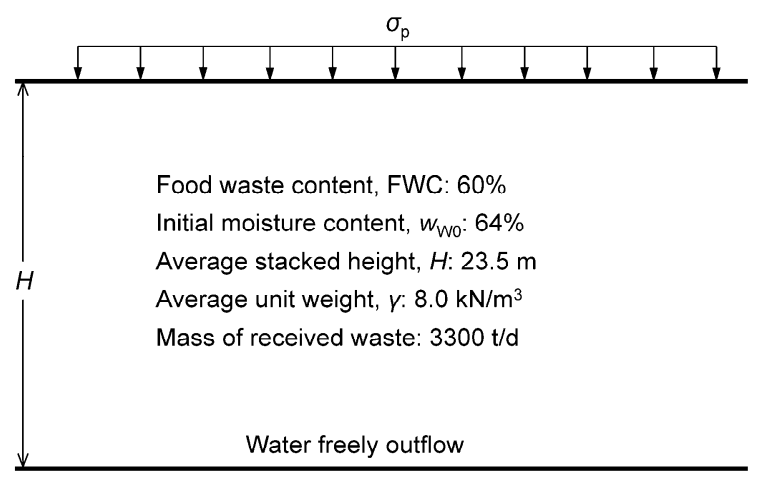

Fig. 11 Profile of simplified MSW pile with initial and boundary conditions

Fig. 12 shows the calculated results of leachate production at the pre-treatment container. The leachate production increased from 704 to $854 \mathrm{t} / \mathrm{d}$ as the drained time went from $1 \mathrm{~d}$ to $7 \mathrm{~d}$. It also shows that the calculated results are in agreement with the measured data when draining for $3-4 \mathrm{~d}$, 
indicating that the proposed MRC model is quite reliable.

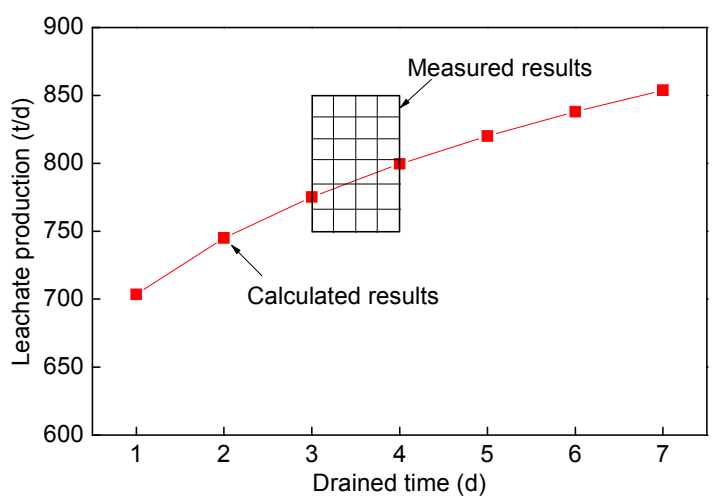

Fig. 12 Leachate production with drained time at pretreatment container

\subsection{Measures to enhance the dewatering effect of MSW pile}

Since the MRC model is verified with the leachate production at the pre-treatment container of Laogang Incineration Plant, in this section three cases are studied to investigate the dewatering effect with different measures.

A similar numerical model to Fig. 11 was adopted in this section, and the parameters $\mathrm{MRC}^{*}, \sigma^{*}$, $C_{0}, C_{\infty}$, and $w_{\mathrm{w} 0}$ are the same as those used in Section 5.1. All the parameters related to the three cases are shown in Table 4. Case 1 was set to research the effect of degradation conditions on the dewatering performance of the MSW pile. Three pairs of the values of $m$ and $n$ were adopted from Table 3 to simulate the three typical degradation conditions. Case 2 was to study the effect of surcharge loading on the dewatering performance with a poor degradation condition. The applied surcharge loadings steps were $0,50,100$, and $200 \mathrm{kPa}$. Case 3 was to investigate the effect of surcharge loading on the dewatering performance with an enhanced degradation condition. The same loading steps were adopted as with case 2 .

Fig. 13a shows the leachate production rate of the MSW pile under different degradation conditions. The leachate production rate was defined as the mass ratio of leachate production to the stacked MSW. The leachate production rate slightly increased from 0.183 to 0.192 as the drained time went from one to seven days under anaerobic degradation with ambient air temperature. However, the leachate production rate increased from 0.205 to 0.247 under anaerobic degradation with a favorable temperature of $(40 \pm 3)^{\circ} \mathrm{C}$, and from 0.214 to 0.259 for the scenario of semi-aerobic degradation with the temperature of $(40 \pm 3)^{\circ} \mathrm{C}$. It was clear that the difference values of leachate production rate between each pair of the three curves tended to increase with drained time.

Fig. 13b shows the leachate production rate of the MSW pile under the scenarios of incremental surcharge loadings and a poor degradation condition. The leachate production rate increased from 0.183 to 0.192 as the drained time went from one to seven days for the scenario of $\sigma_{\mathrm{p}}=0 \mathrm{kPa}$, while from 0.216 to 0.224 for $\sigma_{\mathrm{p}}=50 \mathrm{kPa}$, from 0.240 to 0.247 for $\sigma_{\mathrm{p}}=100 \mathrm{kPa}$, and from 0.271 to 0.277 for $\sigma_{\mathrm{p}}=200 \mathrm{kPa}$. Note that the difference values of leachate production rate between each pair of the four curves tended to decrease slightly with drained time.

Fig. 13c shows the leachate production rate of the MSW pile under the scenarios of incremental surcharge loadings and enhanced degradation condition. The leachate production rate increased from 0.213 to 0.259 as the drained time went from one to seven days for the scenario of $\sigma_{\mathrm{p}}=0 \mathrm{kPa}$, while from 0.243 to 0.283 for $\sigma_{\mathrm{p}}=50 \mathrm{kPa}$, from 0.264 to 0.301 for $\sigma_{\mathrm{p}}=100 \mathrm{kPa}$, and from 0.292 to 0.324 for $\sigma_{\mathrm{p}}=$

Table 4 Parameters related to the three cases for calculating leachate production

\begin{tabular}{ccccccccccc}
\hline Case & MRC $^{*}(\%)$ & $\sigma^{*}(\mathrm{kPa})$ & $C_{0}$ & $C_{\infty}$ & $w_{\mathrm{w} 0}(\%)$ & $m\left(\mathrm{~d}^{-1}\right)$ & $n$ & $H(\mathrm{~m})$ & $\gamma\left(\mathrm{kN} / \mathrm{m}^{3}\right)$ & $\sigma_{\mathrm{p}}(\mathrm{kPa})$ \\
\hline 1 & 18.5 & 120000 & -0.125 & -0.067 & 64 & 0.005, & 0.98, & 23.5 & 10.1 & 0 \\
& & & & & & $0.08,0.11$ & $0.58,0.53$ & & & \\
2 & 18.5 & 120000 & -0.125 & -0.067 & 64 & 0.005 & 0.98 & 23.5 & 10.1 & 0,50, \\
& & & & & & & & & & 100,200 \\
3 & 18.5 & 120000 & -0.125 & -0.067 & 64 & 0.11 & 0.53 & 23.5 & 10.1 & 0,50, \\
& & & & & & & & & & 100,200 \\
\hline
\end{tabular}



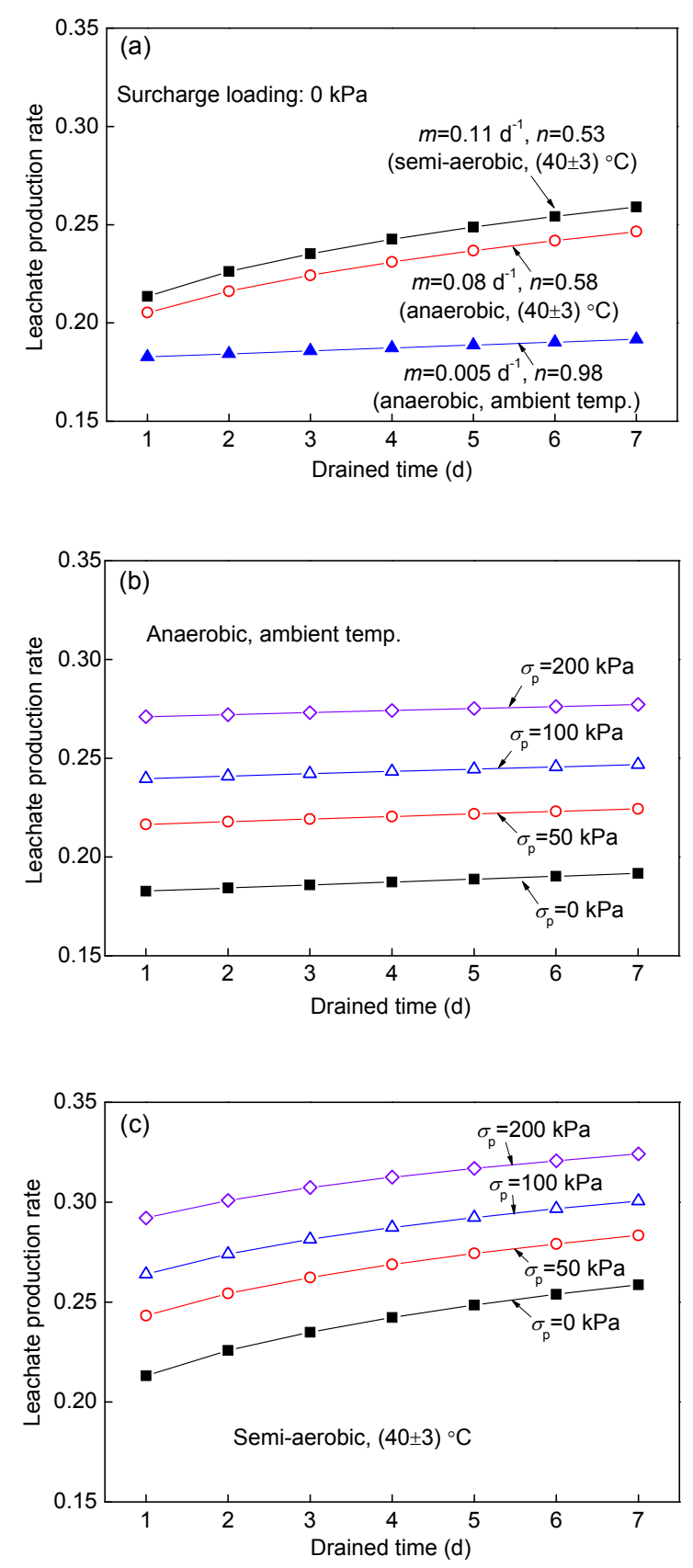

Fig. 13 Leachate production rate under different conditions: (a) different degradation conditions; (b) incremental surcharge loadings and a poor degradation condition; (c) incremental surcharge loadings and an enhanced degradation condition

$200 \mathrm{kPa}$. It was observed that the leachate production rate was much larger in Fig. 13c than that in Fig. $13 \mathrm{~b}$ at a given stress.

The above analyses indicate that the degradationenhancing measures, i.e., temperature elevation and air introduction, can promote the leachate production of the MSW pile, and the contribution becomes more significant with the drained time. In addition, the stress-increasing measures, i.e., surcharge loading application, could significantly enlarge the leachate production of the MSW pile, but the contribution seems to weaken with the drained time. The results also demonstrated that the strategy of combining the degradation-enhancing measures with stressincreasing measures is more effective in the rapid dewatering of the MSW pile. Other degradationenhancing measures, e.g., aerobic degradation or anaerobic degradation with hydrolytic enzyme addition, and stress-increasing measures, e.g., stack height increase, could also be adopted in engineering practice. However, an excessive compression of the MSW pile must be avoided to guarantee an adequate porosity for leachate drainage and gas flow.

\section{Conclusions}

Five sets of MRC tests were conducted on HFWC-MSW, NFWC-MSW, and decomposed MSW. They were performed to characterize the variation of MRC with degradation time and overburden stress. Based on the test results, the evolution mechanism was analyzed, and a time- and stress-dependent model was proposed. Some conclusions and suggestions are:

1. The MRC of fresh HFWC-MSW decreased with degradation time under a sustained stress. This process can be described with the equation $\operatorname{MRC}(t)=$ $\mathrm{MRC}_{0}-\Delta \mathrm{MRC}\left[1-\exp \left(-m t^{n}\right)\right]$. Both the initial and final MRCs of HFWC-MSW were close for the tests under different degradation conditions. The variation process of MRC was significantly related to the degradation condition, and the rising of waste temperature and introduction of oxygen would result in a faster decline of MRC for fresh HFWC-MSW.

2. The MRCs decreased with stress for fresh HFWC-MSW, fresh NFWC-MSW, and decomposed MSW. These processes can be described with the equation $\operatorname{MRC}(\sigma)=A-B \lg \sigma$. The MRC of HFWCMSW was higher than that of NFWC-MSW under a given stress, and the decomposed MSW took the second place. The MRC dropped after the application of an incremental stress, and further decreased 
in the following days. The variation of MRC was independent of stress path in terms of stress and degradation time.

3. The influence mechanism of degradation to the MRC of HFWC-MSW is to reduce the intraparticle water and increase the inter-particle water. The decline rate of MRC depends on the difference between the reduction rate of intra-particle water and the increasing rate of inter-particle water. In addition, the influence mechanism of stress compression is to reduce both the intra-particle water and inter-particle water.

4. A time- and stress-dependent model was proposed for predicting the MRC of HFWC-MSW. The results calculated from the model were in good agreement with the data measured from the pretreatment container of the Laogang Incineration Plant. In addition, the model was applied to evaluate the measures to enhance the dewatering effect of the HFWC-MSW pile. The strategy of combining the degradation-enhancing measures with stressincreasing measures is recommended in the rapid dewatering of an HFWC-MSW pile.

The model presented in this paper is relatively simple and convenient, and can provide an approximate estimate of MRC of HFWC-MSW during the design stage. Further research is required to make these parameters of the model more applicable for the field project in China and even the whole world.

\section{References}

Arif, K.N., 2010. Determination of Hydro-mechanical Characteristics of Biodegradable Waste-Laboratory and Landfill Site. PhD Thesis, University of Grenoble, Grenoble, France (in French).

Beaven, R.P., 2000. The Hydrogeological and Geotechnical Properties of Household Waste in Relation to Sustainable Landfilling. PhD Thesis, Queen Mary and Westfield College, University of London, UK.

Blight, G., 2008. Slope failures in municipal solid waste dumps and landfills: a review. Waste Management \& Research, 26(5):448-463. http://dx.doi.org/10.1177/0734242X07087975

Chen, Y.M., Zhan, T.L., Wei, H.Y., et al., 2009. Aging and compressibility of municipal solid wastes. Waste Management, 29(1):86-95.

http://dx.doi.org/10.1016/j.wasman.2008.02.024

de Velásquez, M.T.O., Cruz-Rivera, R., Rojas-Valencia, N., et al., 2003. Determination of field capacity of municipal solid waste with surcharge simulation. Waste Management \& Research, 21(2):137-144.
http://dx.doi.org/10.1177/0734242X0302100207

Fang, F., Abbas, A.A., Chen, Y.P., et al., 2012. Anaerobic/ aerobic/coagulation treatment of leachate from a municipal solid wastes incineration plant. Environmental Technology, 33(8):927-935. http://dx.doi.org/10.1080/09593330.2011.602435

Fu, Z., Zhang, S., Li, X., et al., 2015. MSW oxy-enriched incineration technology applied in China: combustion temperature, flue gas loss and economic considerations. Waste Management, 38:149-156. http://dx.doi.org/10.1016/j.wasman.2014.12.026

Fungaroli, A.A., Steiner, R.L., 1979. Investigation of Sanitary Landfill Behaviour. Report No. EPA-600/2-79-053a, Environmental Protection Agency, Ohio, USA.

Jang, Y.S., 2000. Analysis of flow behavior in a landfill with cover soil of low hydraulic conductivity. Environmental Geology, 39(3-4):292-298. http://dx.doi.org/10.1007/s002540050008

Koerner, R.M., Soong, T.Y., 2000. Leachate in landfills: the stability issues. Geotextiles and Geomembranes, 18(5): 293-309. http://dx.doi.org/10.1016/S0266-1144(99)00034-5

Lan, J.W., 2012. Mechanism of Leachate Generation, Transport and Mound in MSW Landfills and Control of Leachate Level. PhD Thesis, Department of Civil Engineering, Zhejiang University, Hangzhou, China (in Chinese).

Nie, Y.F., 2008. Development and prospects of municipal solid waste (MSW) incineration in China. Frontiers of Environmental Science \& Engineering in China, 2(1): $1-7$.

http://dx.doi.org/10.1007/s11783-008-0028-6

Rowe, R.K., Nadarajah, P., 1996. Estimating leachate drawdown due to pumping wells in landfills. Canadian Geotechnical Journal, 33(1):1-10.

http://dx.doi.org/10.1139/t96-020

Schwarzbauer, J., Heim, S., Brinker, S., et al., 2002. Occurrence and alteration of organic contaminants in seepage and leakage water from a waste deposit landfill. Water Research, 36(9):2275-2287. http://dx.doi.org/10.1016/S0043-1354(01)00452-3

Tu, F., Qian, X.D., Cui, G.Q., et al., 2008. Study on water holdup of municipal solid waste. Chinese Journal of Rock Mechanics and Engineering, 27(S2):3305-3311 (in Chinese).

Tu, F., Ke, Q.J., Xie, Z.M., et al., 2010. Experimental study on water holdup of municipal solid waste. Chinese Journal of Environmental Engineering, 4(12):2860-2864 (in Chinese).

Wall, D.K., Zeiss, C., 1995. Municipal landfill biodegradation and settlement. Journal of Environmental Engineering, 121(3):214-224. http://dx.doi.org/10.1061/(asce)0733-9372(1995)121:3(214)

Zhan, T.L.T., Xu, X.B., Chen, Y.M., et al., 2015. Dependence of gas collection efficiency on leachate level at wet 
municipal solid waste landfills and its improvement methods in China. Journal of Geotechnical and Geoenvironmental Engineering, 141(4):04015002. http://dx.doi.org/10.1061/(asce)gt.1943-5606.0001271

Zhang, D.Q., He, P.J., Shao, L.M., et al., 2008. Biodrying of municipal solid waste with high water content by combined hydrolytic-aerobic technology. Journal of Environmental Sciences, 20(12):1534-1540.

http://dx.doi.org/10.1016/S1001-0742(08)62562-0

Zhang, W., Zhang, L., Li, A., 2015. Anaerobic co-digestion of food waste with MSW incineration plant fresh leachate: process performance and synergistic effects. Chemical Engineering Journal, 259:795-805. http://dx.doi.org/10.1016/j.cej.2014.08.039

Zornberg, J.G., Jernigan, B.L., Sanglerat, T.R., et al., 1999. Retention of free liquids in landfills undergoing vertical expansion. Journal of Geotechnical and Geoenvironmental Engineering, 125(7):583-594.

http://dx.doi.org/10.1061/(asce)1090-0241(1999)125:7(583)

\section{中文概要}

\section{题 目：考虑应力和时间作用的高厨余含量生活垃圾的 持水量预测模型：基于试验现象}

目 的: 我国城市生活垃圾厨余含量高, 导致初始含水 量高, 从而带来填埋场渗滤液水位高、堆体稳
定性低、填埋气难以收集以及焚烧厂焚烧热值 低、能耗大等问题。研究降解时间和上覆应力 对高厨余垃圾持水量的影响, 提出快速降低高 厨余垃圾的持水量的方法, 大幅减小进场 （厂）垃圾的含水量, 避免上述问题的发生。

创新点：1. 获得高㕑余垃圾的持水量随降解时间和上覆 应力的变化规律; 2. 建立考虑时间和应力作用 的垃圾持水量预测模型。

方 法: 1. 通过开展试验, 分析高厨余垃圾的持水量随 降解时间和上覆应力的变化（图 3 和 5)；2. 基 于试验结果, 分析持水量变化机理 (图 7), 并 建立持水量预测模型（公式 6)；3. 通过对比分 析多种脱水方案的计算结果, 提出高㴻余垃圾 堆体的快速脱水方法（图 13）。

结 论: 1. 高厨余垃圾的持水量随降解时间呈复合指数 形式下降, 随应力的对数线性下降; 2. 降解作 用能够降低胞内水并增大孔隙水持有量, 应力 作用则同时降低胞内水和孔隙水持有量; 3. 持 水量模型计算结果与工程案例实测结果吻合较 好, 并进一步提出了采取加速降解和增大应力 相联合的措施以实现高厨余垃圾快速脱水的 目的。

关键词：城市生活垃圾; 持水量; 应力; 降解时间; 模型 